\title{
Factors Affecting Parents' Decision Making in Choosing a School Private for Children during The Covid-19 Pandemic
}

\author{
Tukiyo $^{1}$, Bayu Indrayanto ${ }^{2}$, Sri Budiyono ${ }^{3 *}$ )
}

1, 2, 3 Faculty of Teacher Training and Education, Widya Dharma University

tukiyo@unwidha.ac.id bayuindra@unwidha.ac.id sribudiyono15@gmail.com

\begin{tabular}{ll}
\hline Article History & Received : June $9^{\text {th } 2021}$ \\
& Revision : August $13^{\text {th } 2021}$ \\
& Publication : Sept 30 2021 \\
\hline
\end{tabular}

\begin{abstract}
The purpose of this study was to examine the factors that influence the way parents make decisions in choosing their favorite private school for their children during the COVID-19 pandemic. These factors are presented starting from the most influential to the smallest. In detail, the purpose of this study is to obtain answers to the questions: (1) what factors influence the way parents make decisions in choosing a favorite private school for their children, (2) are there differences in the decision-making factors of parents in choosing a school? private sector for children between before the pandemic and after the covid-19 pandemic, (3) is there a difference in the income of parents before the pandemic and after the covid-19 pandemic, and (4) how is the level of anxiety of parents in dealing with the covid-19 pandemic. This study uses a quantitative descriptive approach which is intended to describe the factors that influence parents' decision making in choosing private schools for their children during the COVID-19 pandemic. The results showed: 1 . The factors that influence parents' decision making in choosing private schools for children during the covid-19 pandemic are: (1) good religious education factors in schools, (2) good academic achievement, (3) good nonacademic achievement, (4) easy access to school locations, (5) schools have complete learning facilities, (6) good extra-curricular activities, (7) school safety, (8) relatively close distance from the school house, and (9) as a solution due to busy parents
\end{abstract}

Keywords: Decision Making, Private School, Anxiety Level, Academic Achievement, Non-academic Achievement

\section{INTRODUCTION}

Education is an important issue to improve the quality of human resources, both formal, informal and non-formal education. Education for children is obtained in the internal environment of the family, school, and community. The three educational environments will affect the development of children according to their respective potentials. Therefore, parents have an important role in facilitating children to develop well in the educational environment.

In relation to formal education for children, there are various schools, both public and private, with their respective advantages and disadvantages. At the beginning of the twenty-first century, Suyanto and Abbas (2001: 94) stated that in general people in Indonesia want their children to be able to attend public schools, because the mindset of our society is country-minded. However, in recent 
developments, many parents have also chosen private schools as places for their children's education. In several areas in Indonesia, private schools have developed with certain advantages that attract the interest of both parents and their children.

There are several factors that influence parents and their children in choosing a private school. The results of the research by Iriawan and Silvianita (2016) show that the selection of private schools is influenced by the quality of teaching teachers. This research is relevant to the results of Krismawintari's research (2019) which states that the selection of private schools is influenced by the quality or competence of teachers and the image of the school. In schools based on Islam, the selection of private schools is influenced by the wishes of parents with the aim that their children are able to read the Qur'an, and can focus on forming Islamic characters such as being obedient to parents, teachers, honest, religious obedient. , and able to memorize short letters in the Qur'an (Sari, 2018). This is an internal factor in the parents of students. In addition, there are also external factors that influence parents in choosing private schools for their children, namely because usually the school has a vision and mission in shaping children's character Islamically and a curriculum that is adapted to the expectations of parents (Sari, 2018). The results of this study support the research of Asiah and Isnaeni (2018) which states that the selection of private schools is influenced by the superiority of science, noble character, solutions to busy parents, having a reliable marketing strategy, and having superior competitiveness. Kennedy (2018) admits that determining which private school to choose is not an easy decision. With so many schools to choose from, the matter of choosing a school is not simple by any standards. Several aspects about the school and children must of course also be considered before arriving at a final decision.

The results of observations of private schools in Klaten Regency which have a lot of followers, these schools have closed the period of accepting new students long before public schools start accepting new students in the same academic year. This shows that quality private schools will be the choice for some parents to send their children to school. Researchers deem it necessary to conduct this research, especially in Klaten Regency, which is related to the main factors that influence parents' decision making in choosing private schools as places of education for their children. This research is focused on private elementary schools in Klaten Regency.

\section{METHOD}

This study uses a quantitative descriptive approach which is intended to describe the factors that influence parents' decision making in choosing private schools for children during the COVID-19 pandemic.

This research was conducted in August-September 2020, at the Muhammadiyah Tonggalan Elementary School, Central Klaten District, Klaten Regency, Central Java Province.

The subjects of this study were parents of students at private elementary schools in Klaten Regency whose children entered school in the 2019/2020 school year 
(before the covid-19 pandemic) and the 2020/2021 school year (after the covid-19 pandemic). This is intended as a comparison between before and after the COVID-19 pandemic.

To collect data in this study using a questionnaire. The questionnaire was submitted to parents online or online (on the network) through the school. In this case, the questionnaire is made in the form of a google form so that parents of students can fill in from their respective homes using mobile phones or laptops.

After the data has been collected in this study, it is then described to find the dominant factors that influence parents' decision making in choosing private schools for their children. For this purpose, percentage analysis is used.

\section{RESULTS AND DISCUSSION}

From the questionnaires submitted to respondents online, there were 56 people who responded by filling out the questionnaire through the google form provided. Of the 56 people, 25 people (44.6\%) were men and 31 people $(55.5 \%)$ were women. In terms of education level, 2 people (3.6\%) graduated from junior high school/equivalent, 17 people (30.4\%) graduated from high school/equivalent, 13 people $(23.2 \%)$ graduated from diploma, 19 people (33.9\%) graduated Bachelor (S-1)/Diploma IV, and 4 people (7.1\%) graduated Master (S-2). In terms of age, 40 people $(71.4 \%)$ were between $30-40$ years old, 13 people (23.2\%) were between 41-50 years old, and only 3 people (5.4\%) were over 50 years old. . Judging from the type of work of the respondents, 14 people (25\%) as Civil Servants, 4 people (7.1\%) as Police, 2 people (3.6\%) as Armed Forces of the Republic of Indonesia, 6 people (10.7\%) as traders, 12 people $(21.4 \%)$ as private employees, and the remaining 18 people $(32.1 \%)$ work in other informal sectors. From the data, it can be seen that most of the parents of students have Bachelor/Diploma IV education, most of them are between 30-40 years old, and most of them work in the informal sector.

Of the total respondents, 38 people $(67.8 \%)$ of the respondents stated that there was no effect of the COVID-19 pandemic on their income, in the sense that their average income remained the same between before the pandemic and after the Covid-19 pandemic occurred. As many as 14 people (25\%) stated that the covid-19 pandemic affected their income so that their income decreased after the covid-19 pandemic occurred. What's interesting is that due to the COVID-19 pandemic, their income has increased, which is as many as 4 people (7.1\%). This means they can take advantage of opportunities in this pandemic situation.

Prior to the COVID-19 pandemic, the respondent's income was: 2 people $(3.6 \%)$ earning around Rp. 1,000,000.00; 9 (16.1\%) people earn between Rp. 1,000,000.00 Rp. 2,000,000.00; 12 people (21.4\%) earn between Rp. 2,000,000.00 - Rp. 3,000,000.00; 20 people (35.7\%) earn between IDR 3,000,000.00 - IDR 5,000,000.00; 5 people $(8.9 \%)$ earn between IDR $5,000,000$ - IDR 7,500,000; 4 people $(7.1 \%)$ earn between IDR $7,500,000.00$ - IDR 10,000,000.00; and 3 people (5.4\%) earn more than IDR 10,000,000.00. After the covid-19 pandemic occurred, the respondent's income was: 2 
people (3.6\%) earning less than Rp. 1,000,000.00; 4 people (7.1\%) earn around Rp. 1,000,000.00; 4 (7.1\%) people earn between Rp. 1,000,000.00 - Rp. 2,000,000.00; 19 people (33.9\%) earn between Rp. 2,000,000.00 - Rp. 3,000,000.00; 17 people $(30.4 \%)$ earn between Rp. 3,000,000.00 - Rp. 5,000,000.00; 4 people (7.1\%) earn between Rp. $5,000,000.00$ - Rp. 7,500,000.00; 4 people (7.1\%) earn between IDR 7,500,000.00 - IDR $10,000,000.00$; and 2 people (3.4\%) earn more than IDR 10,000,000.00.

From these data, it can be seen that the income of parents before the covid-19 pandemic was mostly (35.7\%) ranging from Rp. 3,000,000.00 - Rp. 5,000,000.00 and by 21.4\%, it was between Rp. 2,000,000.,000,000.00. After the Covid-19 pandemic occurred, the condition was reversed, most of the parents' income $33.9 \%)$ ranged between Rp. 2,000,000.00 - Rp. 3,000,000.00 and by 30.4\%, it was between Rp. $3,000,000 ., 00$.

A total of 19 people (33.9\%) of the respondents stated that they were very worried about COVID-19, 30 people (53.6\%) said they were quite anxious, 6 people $(10.7 \%)$ said they were normal, and there was 1 person $(1,8 \%)$ stated that they were not very anxious. Those who state that they are normal and who are not very anxious, of course, need to be given understanding in order to continue to comply with health protocols, such as wearing masks, frequently washing hands with soap and running water, keeping a distance from other people, avoiding crowds, eating enough nutrition, and getting enough rest. From these data, it means that the level of parental anxiety about the presence of COVID-19 is mostly in the moderately anxious category.

Of the total respondents, as many as 8 people (14.3\%) the distance from home to school is less than $1 \mathrm{~km}$, as many as 3 people (5.6\%) the distance from home to school is about $1-2 \mathrm{~km}$, as many as 11 people (19.6\%) the distance from home to school is about $2-3 \mathrm{~km}$, as many as 18 people (32.1\%) the distance from home to school is about $3-5 \mathrm{~km}$, as many as 10 people (17.9\%) the distance from home to school is about $5-10$ $\mathrm{km}$, and as many as 5 people (8.9\%) the distance from home to school is more than 10 $\mathrm{km}$. From these data, it can be seen that the most distance from home to school is in the range of 3-5 km.

Of the total respondents, as many as 31 people (55.4\%) knew school information from themselves because they often passed in front of the school, as many as 3 people (5.6\%) knew school information from neighbors, as many as 13 people (23.2\% ) know school information from friends, and as many as 8 people (14.3\%) know school information through other media. From the data, it can be seen that most parents already know the school information because they often pass around the school.

Data that states the quality of learning in schools are 18 people $(32.1 \%)$ stating that learning in schools is very good, as many as 31 people $(55.4 \%)$ stating that the learning is good, 4 people (7.1\%) stating the learning is sufficient, and there is 1 person $(1.8 \%)$ who stated that the quality of learning in schools is still lacking. From these data, it can be seen that most of the parents stated that the learning process at school was in good category.

On the other hand, the data which states that achievement in school from 18 
people $(32.1 \%)$ states that academic achievement in school is very good, as many as 31 people (55.4\%) state that academic achievement in school is good, as many as 3 people $(5.4 \%)$ stated that academic achievement in school was sufficient, and only 1 person (1.8\%) stated that academic achievement in school was lacking. From these data, it can be seen that most of the parents stated that the academic achievement in school was in the good category.

Meanwhile, there are 16 people (28.8\%). The data states that non-academic achievement in school is very good, as many as 36 people $(64.3 \%)$ state that nonacademic achievement in school is good, as many as 2 people $(3.8 \%)$ state that nonacademic achievement in school is sufficient, and only 1 person $(1.8 \%)$ stated that nonacademic achievement in school was still lacking. From these data, it can be seen that most of the parents stated that non-academic achievement in school was in good category.

Data which states that there are 10 facilities (17.9\%) state that learning facilities in schools are very good, as many as 40 people $(71.4 \%)$ state that learning facilities in schools are good, as many as 3 people (5.4\%) state that learning facilities in schools are sufficient, and only 1 person (1.8\%) stated that learning facilities in schools are still lacking. From these data, it can be seen that most of the parents stated that the learning facilities in the school were in good category.

Other responses that talk about the factors influencing the selection of private schools are described below.

The factors that influence parents in choosing private schools during the COVID19 pandemic can be described as follows.

a. Religious activities in schools are good, chosen by 47 people (83.9\%)

b. Academic achievement in school is good, chosen by 31 people (55.4\%)

c. Good non-academic achievement in school, chosen by 23 people (41.1\%)

d. The location of the school is easy to reach, chosen by 18 people (32.1\%)

e. The school has complete learning facilities, chosen by 12 people $(21.4 \%)$

f. The school has good extra-curricular activities, chosen by 11 people (19.6\%)

g. There is a school safety factor, chosen by 11 people $(19.6 \%)$

h. Distance from home to school is close, chosen by 10 people $(17.9 \%)$

i. Is a solution due to busy parents, chosen by 7 people $(12.5 \%)$

From these data it can be seen that most parents choose private schools as places for children's education influenced by factors of good religious education in schools, then followed by factors of good academic achievement, good non-academic achievements, easy access to school locations, schools have complete learning facilities , good extra-curricular activities, school safety factor, distance from home to school is close, and as a solution due to busy parents. This last factor means that parents mean that the function of the school is as well as a place for child care.

Next is to talk about the discussion in this study. The results of the discussion in this study are as follows below. 
Based on the results of the study, it was found that most parents chose private schools for their children who were not affected by the COVID-19 pandemic. From the beginning, parents had the desire to send their children to private schools, not public schools. This is influenced by several factors that cause parents to make decisions to send their children to private schools. First, the biggest factor is because parents view the school as having a good religious education. This is relevant to the research of Andryana (2009), Verdiyani (2016), Sandira (2018), and Yuliana and Aini (2018).

The second factor is good school academic achievement, and this is relevant to the research of Andryana (2009), Alsauidi (2016), Yuliana and Aini (2018), and Morris and Perry (2019). The third factor is a good non-academic achievement factor, and this is relevant to the research of Khasanah (2012), Verdiyanti (2016), and Sandira (2018). The fourth factor is the easily accessible school location, this is relevant to the research of Andryana (2009), Khasanah (2012), Verdiyani (2016), and Yuliana and Aini (2018).

The fifth factor is that schools have complete learning facilities, this is relevant to the research of Andryana (2009), Yaacob, Osman, and Bachok (2014), Verdiyani (2016), and Yuliana and Aini (2018). The sixth factor is that the school has good extracurricular activities, this is relevant to the research of Andryana (2009), Sandira (2018), and Yuliana and Aini (2018). The seventh factor is the school safety factor, this is relevant to Verdiyani's research (2016). The eighth factor is the distance from home to a close school, this is relevant to the research of Andryana (2009), Khasanah (2012), Verdiyani (2016), and Yuliana and Aini (2018). The ninth factor is a solution because parents are busy, this is relevant to the research of Asiah and Isnaeni (2018). This last factor means that it is interpreted by parents that the function of the school is as well as a place for child care.

\section{CONCLUSION}

Based on the results of research and data analysis as presented in the results and discussion in this paper, this study draws conclusions as follows:

The factors that influence parents' decision making in choosing private schools for children during the covid-19 pandemic are: (1) good religious education factors in schools, (2) good academic achievement, (3) good non-academic achievement, (4) the location of the school is easy to reach, (5) the school has complete learning facilities, (6) good extra-curricular activities, (7) school safety, (8) the distance from home to school is close, and (9) as a solution due to busy parents .

There is no difference in the decision-making factors of parents in choosing private schools for children between before the pandemic and after the covid-19 pandemic.

There is no significant difference in parental income before the pandemic and after the COVID-19 pandemic.

The level of anxiety of parents of students in facing the COVID-19 pandemic is mostly in the category of being quite anxious.

The results showed that religious education was the main factor influencing 
parents' decision making in choosing private schools for their children, both during the COVID-19 pandemic and before the COVID-19 pandemic. Therefore, schools should maintain and improve the advantages of these schools because these advantages are the main attraction for parents to send their children to school. Other factors such as academic achievement, non-academic achievement, completeness of learning facilities, good extra-curricular activities, and school safety are also important factors that need to be considered and improved by schools.

\section{REFERENCES}

Alsauidi, Faisal (2016). "Reasons Influencing Selection Decision Making of Parental Choice of School”. Journal of Research in Education and Science (IJRES). 2(1), 201 211. https://files.eric.ed.gov/fulltex/EJ1105167.pdf

Andryana, Septi (2009). "Faktor yang Mempengaruhi Pemilihan Sekolah Dasar di Kota Depok Menggunakan Metode Proses Analisa Bertingkat." Jurnal Basis Data, 4(1), 24-43. $\quad$ https://docplayer.info/42491368-Analisa-faktor-faktor-yangmempengaruhi-pemilihan-sekolah-dasar-di-kota-depok-menggunakanmetode-proses-analisa-bertingkat.html

Asiah, Nur dan Isnaeni, Ahmad (2018). "Inklinasi Masyarakat Muslim Kelas Menengah terhadap Sekolah Dasar Islam Terpadu di Bandar Lampung.” Al-Tadzkiyyah: Jurnal Pendidikan Islam, 9(2), 291-309.

https://www.researchgate.net/publication/330192115 Inklinasi Masyarakat Muslim Kelas Menengah Terhadap Sekolah Dasar Islam Terpadu di Bandar Lampung

Burgess, Simon; Greaves, Ellen; Vignoles, Anna; \& Wilson, Deborah (2015). "What Parents Want: School Preferences and School Choice". The Economic Journal. 125(September), 1262-1289.

https://onlinelibrary.wiley.com/doi/abs/10.1111/ecoj.12153

Hasan, M. Iqbal (2002). Pokok-pokok Materi Teori Pengambilan Keputusan. Jakarta: Ghalia Indonesia.

Iriawan, Dean Pratiwi \& Silvianita, Anita (2016). "Analisis faktor-faktor yang Mempengaruhi Keputusan Orang Tua Memilih SD Islam A-Azhar 15 Cilacap." $e$ Proceeding of Management, (3)2, 1820-1826.

https://openlibrary.telkomuniversity.ac.id/pustaka/files/116605/jurnal epro c/analisis-faktor-pendorong-yang-mempengaruhi-keputusan-orang-tuamurid-memilih-sd-islam-al-azhar-16-cilacap.pdf

Kennedy, Robert (2018). "Evaluating and Choosing a Private School. Private School Review.” $\quad$ https://www.privateschoolreview.com/blog/evaluating-andchoosing-a-private-school.

Khasanah, Nurul (2012). "Faktor-faktor yang Mempengauhi Orang Tua dalam Pengambilan Keputusan Memilih Sekolah Dasar Swasta (SD Virgo Maria 2 dan SDIP H Soebandi Kecamatan Bawen Kabupaten Semarang)." Satya Widya, 28(2), 137-146. 
https://ejournal.uksw.edu/satyawidya/article/download/130/118.

Krismawintari, Ni Putu Dyah (2019). Faktor-faktor yang Dipertimbangkan Orang Tua dalam Memilih Sekolah (Studi Kasus pada SMPK 1 Harapan Denpasar). Jurnal Undira, 31-44.

https://www.jurnal.undhirabali.ac.id/index.php/pariwisata/article/viewFile/ $119 / 103$.

Morris, Rebecca \& Perry, Thomas (2019). "Private schools for free: Parents' reasons for choosing a new Free School for their child." Cambridge Journal of Education. 49(5), 535-552.

https://www.researchgate.net/publication/331712708 Private schools for $\mathrm{fr}$ ee Parents' reasons for choosing a new Free School for their child

Mulyono, Sri (1996). Teori Pengambilan Keputusan. Jakarta: Lembaga Penerbit Fakultas Ekonomi Universitas Indonesia.

Muslich, Muhammad (2009). Metode Pengambilan Keputusan Kuantitatif. Jakarta: Bumi Aksara.

Sandria, Andri Nusa (2018). Analisis Faktor-faktor yang Mempengaruhi Pengambilan Keputusan Orang Tua Siswa Kelas 1 dalam Memilih Sekolah Dasar Berbasis Agama di SD Muhammadiyah 16 Surakarta Tahun Ajaran 2017/2018. Surakarta: Institusional Repository Universitas Muhammadiyah Suirakarta. http://eprints.ums.ac.id/63316/2/.pdf

Sari, Desi Puspita (2018). Motivasi Orang Tua dalam Memilih Sekolah Dasar Islam Terpadu bagi Anak (Penelitian pada Orang Tua Murid di SDIT Nurul Ishlah Kecamatan Ulee Kareng Kota Banda Aceh). Aceh: Electronic Thesis and Disertations Insyiah.

https://etd.unsyiah.ac.id/baca/index.php?id=51257\&page=1

Suyanto dan Abbas, M. S. (2001). Wajah dan Dinamika Pendidikan Anak Bangsa. Yogyakarta: Adicita Karya Nusa.

Undang-Undang Nomor 20 Tahun 2003 tentang Sistem Pendidikan Nasional. Jakarta: Sinar Grafika.

Usman, Husaini (2008). Manajemen: Teori, Praktik, dan Riset Pendidikan. Jakarta: Bumi Aksara.

Yaacob, Nur Alyani; Osman, Maria Mohamed; Bachok, Syahirah (2014). "Factors Influencing Parents' Decision in Choosing Private Schools". Procedia-Social and Behavioral Sciences. 153(Oktober), 242-253.

https://www.sciencedirect.com/science/article/pii/S1877042814055001/pd f?md5=bb8ca370905cf5012b196a78e1062088\&pid=1-s2.0S1877042814055001-main.pdf

Yuliana, Kenti dan Aini, Ahmad (2018). "Sistem Pendukung Keputusan Pemilihan Sekolah Dasar Menggunakan Metode Analytic Hierarchy Process (AHP) pada Gugus Sungai Jingah Kecamatan Banjarmasin Utara". Jurnal AMIK/Infokam, 14(1), 124-133. 
Volume 5 Number 1 September 2021

http://amikjtc.com/jurnal/index.php/jurnal/article/view/143

Verdiana, Ristaulina (2016). "Analisis Animo Masyarakat dalam Memilih Sekolah Anak di SD Wuluhadeg dan SDIT Assalam". Jurnal Pendidikan Guru Sekolah Dasar, 23(5), 262-269.

https://www.google.com/search?safe=strict\&q 